\title{
Behaviors of Nuclear Fuel Cladding During RIA
}

\author{
Sun-Ki Kim \\ Korean Atomic Energy Research Institute \\ Republic of Korea
}

\section{Introduction}

A Reactivity-initiated accident (RIA) is a nuclear reactor accident that involves an unwanted increase in reactor power. The abrupt power increase can lead to damage the reactor core as well as fuel cladding, and in severe cases, even lead to disruption of reactor.

During a steady-state operation of light water reactors, the mechanical behavior of the zirconium-based fuel cladding degrades due to a combination of oxidation, hydriding, and radiation damage. In an effort to increase the operating efficiency through the use of longer fuel cycles, and to reduce the volume of waste associated with the core reloads, utilities have a strong incentive to increase the average discharge burn-up of the fuel assemblies. Further increases in the operating efficiency of power reactors can also be achieved by increasing the coolant outlet temperature. However, both of these changes in a reactor operation enhance the cladding degradation, which may increase the likelihood of a cladding failure during design-basis accidents.

One such postulated design-basis accident scenario is the reactivity-initiated accident (RIA) in a pressurized water reactor (PWR) caused by the ejection of a control rod from the core, which would cause a rapid increase of the reactivity and the thermal energy in the fuel (Meyer et al., 1986). The increase in fuel temperature resulting from an RIA induces a rapid fuel expansion, causing a severe pellet-cladding mechanical interaction (PCMI). This PCMI forces the cladding to experience a multiaxial tension such that the maximum principal strain is in the hoop (i.e., transverse) direction of the cladding tube. The survivability of a fuel cladding irradiated to a high burn-up under postulated RIA conditions is thus a response to a combination of the mechanics of a loading and the material degradation during a reactor operation.

While such data is available for the axial deformation behavior of cladding tubes, relatively little data has been reported in the open literature on the uniaxial tension behavior in the hoop direction of nuclear fuel cladding. In the 1990s, experimental programs were also initiated in Japan, France, and Russia to investigate the behavior of highly irradiated nuclear fuel under reactivity-initiated accident conditions.

Accordingly, it is essential to investigate the uniaxial tension behavior in the hoop direction of nuclear fuel cladding. In this chapter, some mechanical tests results for simulating the cladding behaviors during reactivity-initiated accident are introduced. 


\section{International test program: CABRI program}

In a pressurized water reactor, the reactivity initiated accident (RIA) scenario of primary concern is the control rod ejection accident (Glasstone \& Sesonske, 1991). At this early heatup stage of the RIA, the clad tube material is still at a fairly low temperature $(<650 \mathrm{~K})$, and the fast straining imposed by the expanding fuel pellets may therefore cause a rapid and partially brittle mode of clad failure (Chung \& Kassner, 1998). To investigate fuel behaviors during these RIA condition, CABRI REP-Na test program was initiated in early 1990s. The main purpose of the CABRI REP-Na test program was to study the validity of the RIA acceptance criteria on high-burnup $17 \times 17$ PWR fuel, with emphasis on the behavior of fuel during the early stage of the transient up to fuel failure (Schmitz \& Papin, 1999). Recently, international test program in CABRI has being prepared in order to simulate the fuel behaviors in water loop at reactor pressure level by replacing the existing $\mathrm{Na}$ loop with water loop. Through a total of 15 technical advisory group meetings, the test matrix in the CABRI water loop program has being established.

In this chapter, main test results in CABRI REP-Na program are presented, and also the current status on the CABRI water loop program is briefly introduced.

\subsection{CABRI REP Na loop test program}

\subsubsection{Overview of CABRI REP Na loop test}

First of all, a total of twelve tests have been carried out in the program. Eight of the tests were performed on $\mathrm{UO}_{2}$ fuel and four tests on MOX fuel, pre-irradiated to burnups ranging from 28 to $65 \mathrm{MWd} / \mathrm{kgU}$. In addition to the CABRI REP-Na program, two tests were performed in November 2002 on PWR fuel rods with burnups around $75 \mathrm{MWd} / / \mathrm{kgU}$. These test rods, denoted CIPO-1 and CIPO-2, had advanced claddings such as ZIRLO and M5 cladding, respectively. The CABRI test reactor is a pool-type light water reactor, designed with a central flux area that can accommodate the insertion of a test device.

\subsection{Main outcomes of CABRI REP Na loop test}

Fuel cladding failure occurred in four tests, whereas no failure occurred in the remaining 8 tests. Among the four tests with fuel failure, there had $\mathrm{UO}_{2}$ fuel and one MOX fuel. All failures were with Zircaloy-4 cladding, whereas no failure occurred in the three tests with M5 or ZIRLO cladding. The three $\mathrm{UO}_{2}$ failures occurred at enthalpy below $80 \mathrm{cal} / \mathrm{g}$ and on fuel that had a burnup of about $60 \mathrm{MWd} / \mathrm{kgU}$ and significant oxide thickness from 80 to 130 $\mu \mathrm{m}$. However, several other CABRI tests were run at comparable burnup and oxide thickness range, without resulting in fuel failure. Oxide spalling appears to be distinctive

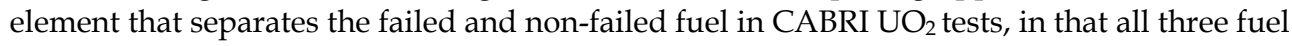
rods that failed had spalling, while the rods that did not fail had uniform non-spalled oxide. Only one test for MOX fuel among four tests resulted in fuel failure. The failure occurred on a fuel rod that had a burnup of $55 \mathrm{MWd} / \mathrm{kgU}$ and moderate corrosion level of $50 \mu \mathrm{m}$ oxide thickness. This is the only CABRI failure occurring on a non-spalled cladding. However, this failure occurred at $113 \mathrm{cal} / \mathrm{g}$, which is a rather high enthalpy level, where a failure may not be surprising, considering that this level in near the upper envelope of all CABRI data. Failures were not associated to a particular pulse width. The three $\mathrm{UO}_{2}$ fuel rod failures 
occurred at all three pulse widths that have been used in CABRI test program, i.e. 9, 30, and $75 \mathrm{~ms}$. The main outcomes from CABRI Na loop test program are listed in Table 1.

\subsection{Current status of CABRI water loop test program}

CABRI international program (CIP) in water loop test has been managed by IRSN in France with collaboration of EDF, CEA and the participating countries with support by OECD/NEA. This program focuses on the high burnup fuel and cladding behaviors in PWR condition during RIA. The test conditions are 155 bar and $280^{\circ} \mathrm{C}$. Five test series were

\begin{tabular}{|c|c|c|c|c|c|}
\hline $\begin{array}{c}\text { Test and } \\
\text { date }\end{array}$ & $\begin{array}{l}\text { Rod and } \\
\text { Burn-up }\end{array}$ & $\begin{array}{l}\text { Pulse } \\
\text { width } \\
\text { (ms) }\end{array}$ & $\begin{array}{c}\text { Energy } \\
\text { Deposition } \\
\text { cal } / g\end{array}$ & $\begin{array}{l}\text { Corrosion } \\
\mu \mathrm{m}\end{array}$ & Results and observations \\
\hline $\begin{array}{c}\mathrm{Na}-1 \\
(11 / 93)\end{array}$ & $\begin{array}{c}\text { GRA } 5 \\
64 \mathrm{MWd} / \mathrm{kg}\end{array}$ & 9.5 & $\begin{array}{c}110 \\
\text { (at } 0.4 \mathrm{~s})\end{array}$ & $\begin{array}{c}80 \\
\text { spalling }\end{array}$ & $\begin{array}{c}\text { Brittle failure at } \mathrm{H}_{\mathrm{F}}=30 \mathrm{cal} / \mathrm{g} \\
\text { Fuel dispersal }(6 \mathrm{~g})\end{array}$ \\
\hline $\begin{array}{c}\mathrm{Na}-2 \\
(6 / 94)\end{array}$ & $\begin{array}{c}\mathrm{BR3} \\
33 \mathrm{MWd} / \mathrm{kg}\end{array}$ & 9.1 & $\begin{array}{c}211 \\
\text { (at } 0.4 \mathrm{~s})\end{array}$ & 4 & $\begin{array}{l}\text { No failure, } \mathrm{H}_{\mathrm{MAX}}=199 \mathrm{cal} / \mathrm{g} \\
\text { Max. strain : 3.5\%, FGR : } 5.5 \%\end{array}$ \\
\hline $\begin{array}{c}\mathrm{Na}-3 \\
(10 / 94)\end{array}$ & $\begin{array}{c}\text { GRA } 5 \\
53 \mathrm{MWd} / \mathrm{kg}\end{array}$ & 9.5 & $\begin{array}{c}120 \\
\text { (at } 0.4 \mathrm{~s})\end{array}$ & 40 & $\begin{array}{l}\text { No failure, } \mathrm{H}_{\mathrm{MAX}}=124 \mathrm{cal} / \mathrm{g} \\
\text { Max. strain : } 2 \%, \mathrm{FGR}: 13.7 \%\end{array}$ \\
\hline $\begin{array}{l}\mathrm{Na}-4 \\
(7 / 95)\end{array}$ & $\begin{array}{c}\text { GRA } 5 \\
62 \mathrm{MWd} / \mathrm{kg}\end{array}$ & 75 & $\begin{array}{c}95 \\
\text { (at } 1.2 \mathrm{~s})\end{array}$ & $\begin{array}{c}80 \\
\text { no spalling }\end{array}$ & $\begin{array}{c}\text { No failure, } \mathrm{H}_{\mathrm{MAX}}=85 \mathrm{cal} / \mathrm{g} \\
\text { Max. strain : } 0.4 \%, \text { FGR : } 8.3 \%\end{array}$ \\
\hline $\begin{array}{l}\mathrm{Na}-5 \\
(5 / 95)\end{array}$ & $\begin{array}{c}\text { GRA } 5 \\
64 \mathrm{MWd} / \mathrm{kg}\end{array}$ & 9.5 & $\begin{array}{c}105 \\
\text { (at } 0.4 \mathrm{~s})\end{array}$ & 20 & $\begin{array}{l}\text { No failure, } \mathrm{H}_{\mathrm{MAX}}=108 \mathrm{cal} / \mathrm{g} \\
\text { Max. strain : } 1 \%, \mathrm{FGR}: 15.1 \%\end{array}$ \\
\hline $\begin{array}{c}\text { Na-6 } \\
(03 / 96)\end{array}$ & $\begin{array}{c}\text { MOX } \\
47 \mathrm{MWd} / \mathrm{kg}\end{array}$ & 35 & $\begin{array}{c}125 \\
\text { (at } 0.66 \mathrm{~s})\end{array}$ & 35 & $\begin{array}{c}\text { No failure, } \mathrm{H}_{\mathrm{MAX}}=133 \mathrm{cal} / \mathrm{g} \\
\text { Max. strain : } 3.2 \% \text {, FGR : } 21.6 \%\end{array}$ \\
\hline $\begin{array}{c}\mathrm{Na}-7 \\
(1 / 97)\end{array}$ & $\begin{array}{c}\text { MOX } \\
55 \mathrm{MWd} / \mathrm{kg}\end{array}$ & 40 & $\begin{array}{c}165 \\
\text { (at } 1.2 \mathrm{~s})\end{array}$ & 50 & $\begin{array}{c}\text { Failure at } \mathrm{H}_{\mathrm{F}}=113 \mathrm{cal} / \mathrm{g} \\
\text { Strong flow ejection }\end{array}$ \\
\hline $\begin{array}{c}\mathrm{Na}-8 \\
(07 / 97)\end{array}$ & $\begin{array}{c}\text { GRA } 5 \\
60 \mathrm{MWd} / \mathrm{kg}\end{array}$ & 75 & $\begin{array}{c}106 \\
\text { (at } 0.4 \mathrm{~s})\end{array}$ & $\begin{array}{c}130 \\
\lim . \text { spalling }\end{array}$ & $\begin{array}{c}\text { Failure at } \mathrm{H}_{\mathrm{F}} \leq 82 \mathrm{cal} / \mathrm{g} \\
\mathrm{H}_{\mathrm{MAX}}=98 \mathrm{cal} / \mathrm{g}, \text { No fuel dispersal }\end{array}$ \\
\hline $\begin{array}{c}\mathrm{Na}-9 \\
(04 / 97)\end{array}$ & $\begin{array}{c}\mathrm{MOX} \\
28 \mathrm{MWd} / \mathrm{kg}\end{array}$ & 34 & $\begin{array}{l}197 \text { at } 0.5 \mathrm{~s} \\
241 \text { at } 1.2 \mathrm{~s}\end{array}$ & $\langle 20$ & $\begin{array}{l}\text { No failure, } \mathrm{H}_{\mathrm{MAX}}=197 \mathrm{cal} / \mathrm{g} \\
\text { Max. strain : } 7.4 \% \text {, FGR : 34\% }\end{array}$ \\
\hline $\begin{array}{l}\mathrm{Na}-10 \\
(07 / 98)\end{array}$ & $\begin{array}{c}\text { GRA } 5 \\
62 \mathrm{MWd} / \mathrm{kg}\end{array}$ & 31 & 107 at $1.2 \mathrm{~s}$ & $\begin{array}{c}80 \\
\text { no spalling }\end{array}$ & $\begin{array}{c}\text { Failure at } \mathrm{H}_{\mathrm{F}}=81 \mathrm{cal} / \mathrm{g} \\
\mathrm{H}_{\mathrm{MAX}}=98 \mathrm{cal} / \mathrm{g}, \mathrm{No} \text { fuel dispersal }\end{array}$ \\
\hline Na-11 & $\begin{array}{c}\mathrm{M} 5 \\
63 \mathrm{MWd} / \mathrm{kg}\end{array}$ & 31 & 104 & 15 & $\begin{array}{c}\text { No failure, } \mathrm{H}_{\mathrm{MAX}}=93 \mathrm{cal} / \mathrm{g} \\
\text { Max. strain : } \sim 0.5 \%\end{array}$ \\
\hline $\mathrm{Na}-12$ & $\begin{array}{c}\mathrm{MOX} \\
65 \mathrm{MWd} / \mathrm{kg}\end{array}$ & 62 & 106 & $\begin{array}{c}80 \\
\text { no spalling }\end{array}$ & No failure, $\mathrm{H}_{\mathrm{MAX}}=103 \mathrm{cal} / \mathrm{g}$ \\
\hline $\begin{array}{l}\text { CIP0-1 } \\
(11 / 02)\end{array}$ & $\begin{array}{c}\text { ZIRLO } \\
75 \mathrm{MWd} / \mathrm{kg}\end{array}$ & 32 & 98 & $\begin{array}{c}80 \\
\text { no spalling }\end{array}$ & No failure, $\mathrm{H}_{\mathrm{MAX}}=90 \mathrm{cal} / \mathrm{g}$ \\
\hline $\begin{array}{l}\text { CIP0-2 } \\
(11 / 02)\end{array}$ & $\begin{array}{c}\text { M5 } \\
77 \mathrm{MWd} / \mathrm{kg}\end{array}$ & 28 & 89 & 20 & No failure, $\mathrm{H}_{\mathrm{MAX}}=81 \mathrm{cal} / \mathrm{g}$ \\
\hline
\end{tabular}

Table 1. Main outcomes from CABRI REP Na test program 
established including qualification test, CIP Q for various fuel pellet, cladding, corrosion level and burnup. The test matrix CABRI international program (CIP) in water loop are listed in Table 2 . The test sequence is not fixed, therefore it may be changed.

\begin{tabular}{|c|c|c|c|}
\hline $\begin{array}{l}\text { Test } \\
\text { Series }\end{array}$ & Test & Test Rod & Objectives \\
\hline CIPQ & & $\begin{array}{l}\text { REP Na6 rod, span 3, 3cycles } \\
\text { MOX, Zr4 }\end{array}$ & CWL qualification + phenomenology \\
\hline CIP1 & $\begin{array}{l}\text { CIP1-2 } \\
\text { (option) }\end{array}$ & $\begin{array}{l}\text { CIP0-2 sister rod, UO2 } \\
77 \mathrm{GWd} / \mathrm{t}, \mathrm{M} 5\end{array}$ & Phenomenology, Code validation \\
\hline CIP2 & CIP2-1 & $\begin{array}{l}\text { UO2 } 85 \text { GWd/t, M5 = reference } \\
\text { or ENUSA rod , 80GWd/t, Zr- } \\
\mathrm{Nb}\end{array}$ & Product qualification, code validation \\
\hline CIP4 & CIP4-1 & $\begin{array}{l}\text { MOX-E M5 EDF rod }(55 \mathrm{GWd} / \mathrm{t}) \\
\text { MOX-SBR-Beznau rod } \\
(54 \mathrm{Gwd} / \mathrm{t}, \mathrm{Zr} 4)\end{array}$ & $\begin{array}{l}\text { Product qualification } \\
\text { Product qualification, physical } \\
\text { understanding }\end{array}$ \\
\hline CIP5 & CIP5-1 & $\begin{array}{l}\text { VVER Lovisa, 50GWd/t, Zr- } \\
1 \% \mathrm{Nb}\end{array}$ & Product qualification \\
\hline \multirow[t]{5}{*}{ CIP3 } & CIP3-1 & CIP0-1 sister rod, span 5 & $\begin{array}{l}\text { Code validation, safety criteria, post- } \\
\text { failure events }\end{array}$ \\
\hline & CIP3-2 & REP Na 7 sister rod & $\begin{array}{l}\text { Code validation, safety criteria, post- } \\
\text { failure events }\end{array}$ \\
\hline & CIP3-3 & $\begin{array}{l}\text { Vandellos CIP0-1 sister rod, } \\
\text { span3, UO2, } 75 \mathrm{GWd} / \mathrm{t}\end{array}$ & $\begin{array}{l}\text { Code validation, safety criteria, } \\
\text { phenomenology }\end{array}$ \\
\hline & CIP3-4 & $\begin{array}{l}\text { EDF rod, M5 } \\
63-68 \mathrm{GWd} / \mathrm{t}\end{array}$ & Product qualification \\
\hline & CIP3-5 & $\begin{array}{l}\text { ENUSA rod, } 67 \mathrm{GWd} / \mathrm{t} \\
\mathrm{Zr}-\mathrm{Nb}\end{array}$ & $\begin{array}{l}\text { Product qualification, physical } \\
\text { understanding }\end{array}$ \\
\hline
\end{tabular}

Table 2. Test matrix CABRI international program

\section{Evaluation of mechanical properties of nuclear cladding}

Except for international test program in pulse reactors, some mechanical tests such as ring tensile test, high-speed burst test, and expansion due-to compression test were applied in order to investigate the stress and strain in pellet-cladding mechanical interaction during RIA. In this chapter, the results on the ring tensile test and the high-speed burst test are introduced.

\subsection{Evaluation of mechanical properties by Ring tensile test}

To obtain the mechanical strengths such as the $0.2 \%$ offset yield strength and ultimate tensile strength were evaluated, and the uniform elongation and total elongation were also 
evaluated for the ductility. The hoop stress-strain curves at various temperatures are shown in Fig. 1.

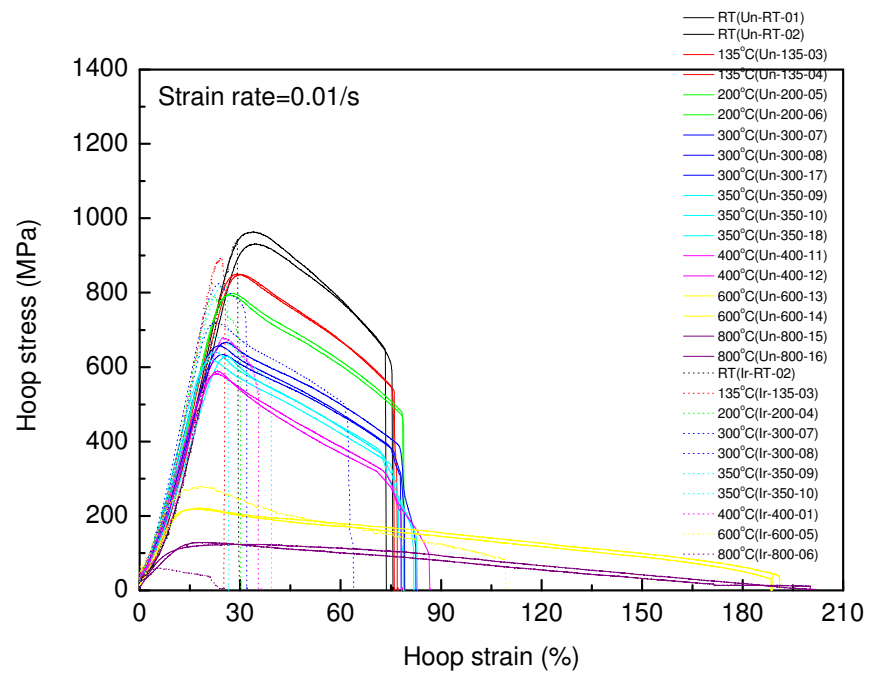

Fig. 1. Hoop stress-strain curves at various test temperatures

The evaluation results of the yield strength and the ultimate tensile strength are shown in Fig. 2 and 3.

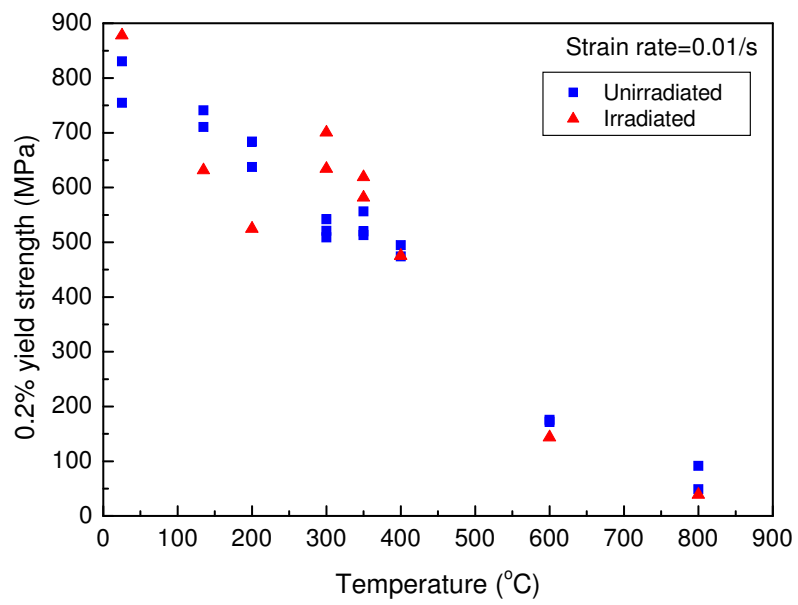

Fig. 2. Yield strength of the un-irradiated and high burn-up fuel cladding 


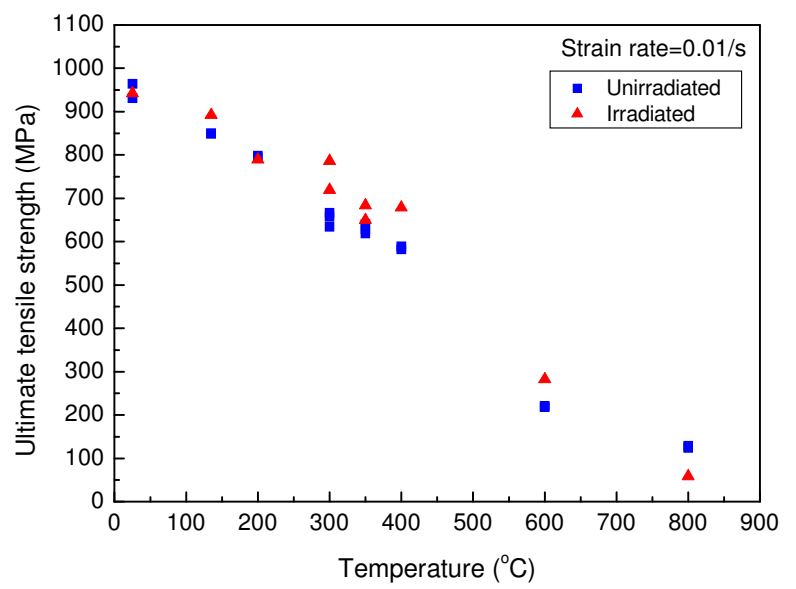

Fig. 3. Ultimate tensile strength of the un-irradiated and high burn-up fuel cladding

The results show that the $0.2 \%$ offset yield strength and the ultimate tensile strength abruptly decrease with an increasing temperature. The ultimate tensile strength was evaluated to be $942.70 \mathrm{MPa}$ at $\mathrm{RT}, 678.83 \mathrm{MPa}$ at $400^{\circ} \mathrm{C}$, but, it is abruptly diminished to $282.64 \mathrm{MPa}$ at $600^{\circ} \mathrm{C}$, which is achievable in the RIA condition. Especially, it decreases to $58.30 \mathrm{MPa}$ at $800^{\circ} \mathrm{C}$, an extreme condition, which corresponds to $6 \%$ of the ultimate tensile strength at room temperature. This means that the mechanical strength of the high burn-up Zircaloy-4 nuclear fuel cladding sharply decreases in the RIA-relevant temperature ranges. The evaluation results of the uniform elongation and total elongation are shown in Fig. 4 and 5 .

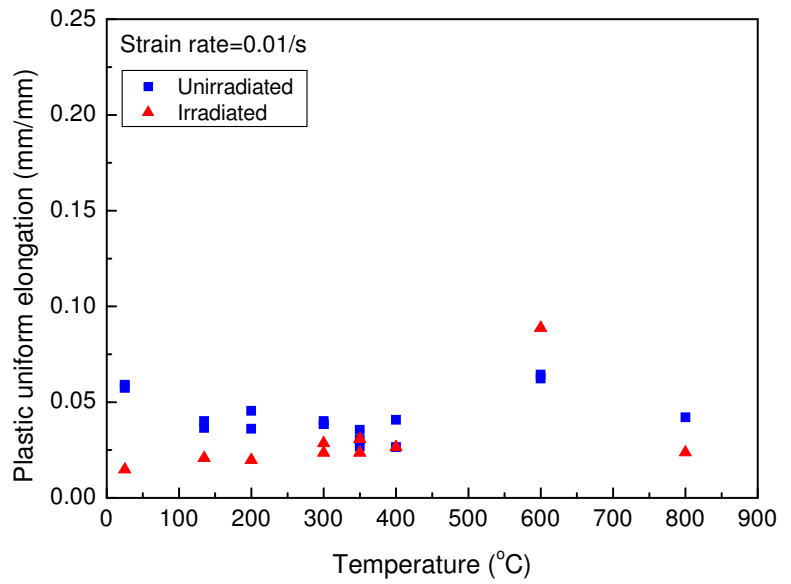

Fig. 4. Uniform elongation of the un-irradiated and high burn-up fuel cladding 


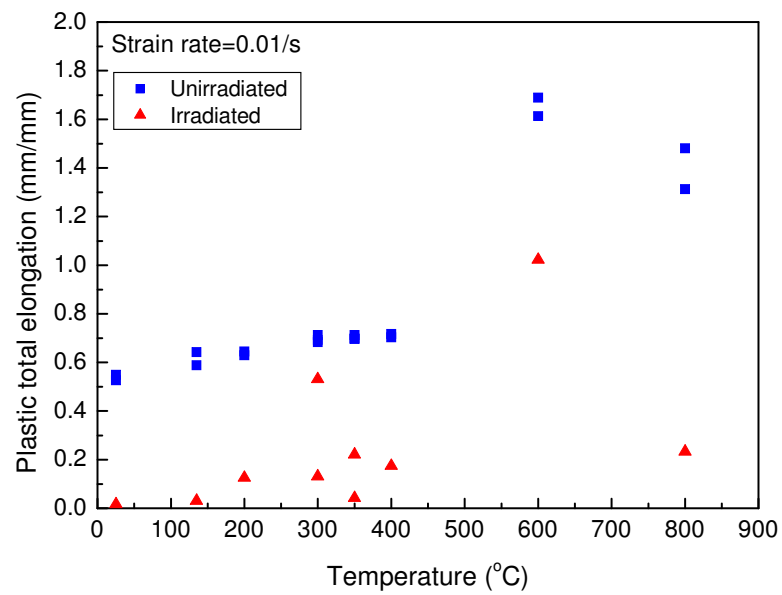

Fig. 5. Total elongation of the un-irradiated and high burn-up fuel cladding

The results show that both the increases in uniform elongation and total elongation with an increasing temperature. Especially, they abruptly increase at $600^{\circ} \mathrm{C}$, but become lower beyond this temperature. This peculiar behavior was also observed in the PROMETRA program (Averty et al., 2003) which is a mechanical property relevant test program in conjunction with the CABRI program simulating a RIA. The results of hoop directional mechanical strength and ductility of irradiated Zircaloy-4 with comparison with PROMETRA database are shown in Fig. 6 and Fig. 7, respectively. As shown in the figure, the behavior of this study is consistent with the PROMETRA data. It is believed that this behavior is caused by the elongation minimum phenomenon by the dynamic strain aging of the $\mathrm{Zr}$-base cladding material beyond $600^{\circ} \mathrm{C}$.

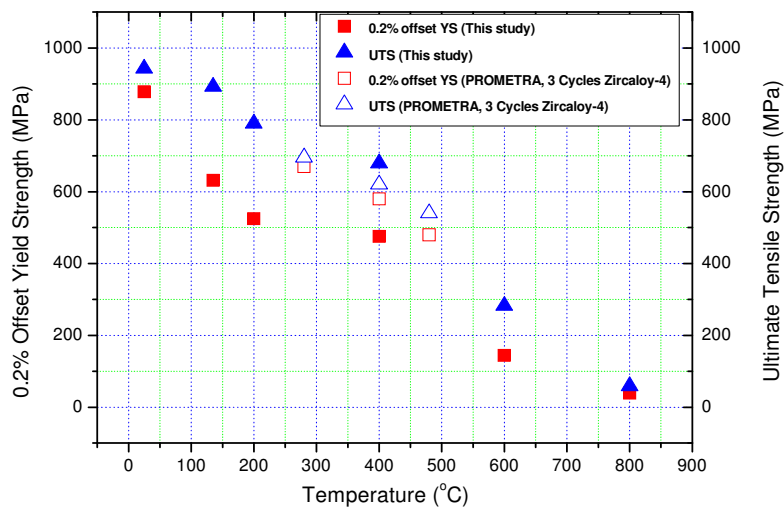

Fig. 6. Comparison of mechanical strength with the PROMETRA database 


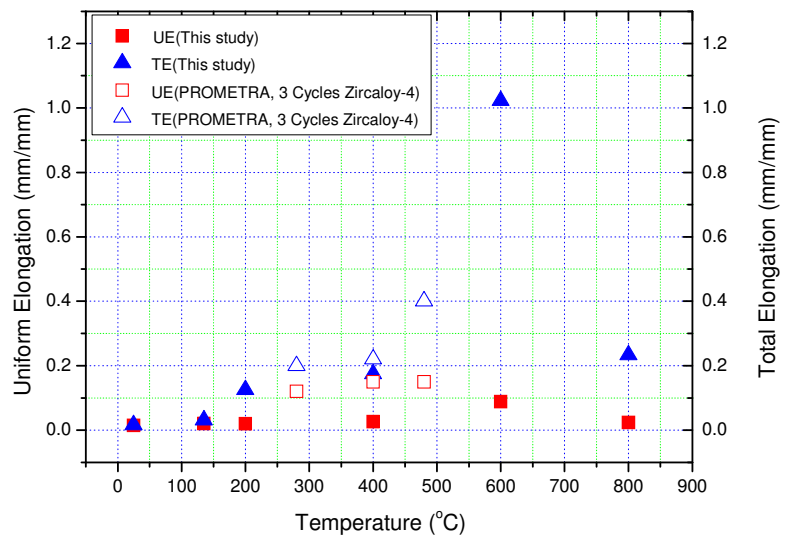

Fig. 7. Comparison of mechanical ductility with the PROMETRA database

The stereoscope photographs of the specimens after the ring tensile test are shown in Fig. 8 . Fig. 8 represents the fracture patterns of the non-irradiated and high burn-up Zircaloy-4 cladding specimens. As shown in the figure, four fracture patterns such as $45^{\circ}$ shear type fracture, cup \& cone type fracture, cup \& cup type fracture and chisel edge type fracture were observed in the non-irradiated cladding.

The fracture type was found to depend strongly on the deformation temperature. At room temperature non-irradiated Zircaloy- 4 cladding tends to be fractured by $45^{\circ}$ shear type fracture or Cup \& cone type fracture. Cup \& cone type fracture was dominant at $135^{\circ} \mathrm{C}$ and $200^{\circ} \mathrm{C}$. Both cup \& cone type fracture and cup \& cup type fracture was observed at $300^{\circ} \mathrm{C}$. Only cup \& cup type fracture was observed at $350^{\circ} \mathrm{C}$ and $400^{\circ} \mathrm{C}$. At $600^{\circ} \mathrm{C}$ chisel edge type fracture was observed unlike at lower temperatures with few fracture surface area. At $800^{\circ} \mathrm{C}$ the fracture type is unclear. These fracture types are summarized in Table 3.

\begin{tabular}{|c|c|c|}
\hline \multirow{2}{*}{ Temperature } & \multicolumn{2}{|c|}{$\begin{array}{ll}\text { Fracture type } \\
\end{array}$} \\
\hline & Non-irradiated cladding & High burn-up cladding \\
\hline $25^{\circ} \mathrm{C}$ & $\begin{array}{l}45^{\circ} \text { shear type fracture } \\
\text { Cup \& cone type fracture }\end{array}$ & \multirow{8}{*}{ Brittle fracture } \\
\hline $135^{\circ} \mathrm{C}$ & Cup \& cone type fracture & \\
\hline $200^{\circ} \mathrm{C}$ & Cup \& cone type fracture & \\
\hline $300^{\circ} \mathrm{C}$ & $\begin{array}{l}\text { Cup } \mathcal{E} \text { cone type fracture } \\
\text { Cup } \mathcal{E} \text { cup type fracture }\end{array}$ & \\
\hline $350^{\circ} \mathrm{C}$ & Cup E cup type fracture & \\
\hline $400^{\circ} \mathrm{C}$ & Cup E cup type fracture & \\
\hline $600^{\circ} \mathrm{C}$ & Chisel edge type fracture & \\
\hline $800^{\circ} \mathrm{C}$ & Unidentified & \\
\hline
\end{tabular}

Table 3. Fracture types for the ring tensile tests of the Zircaloy-4 fuel cladding 
Non-irradiated cladding
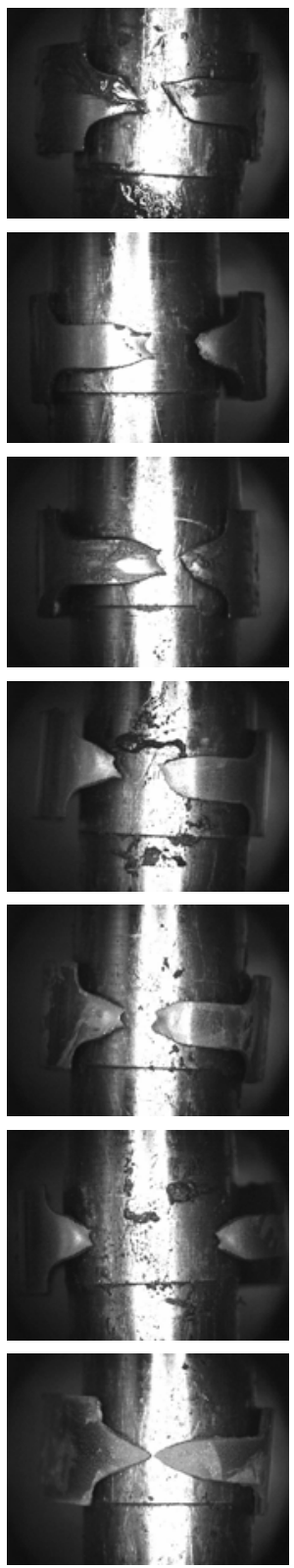
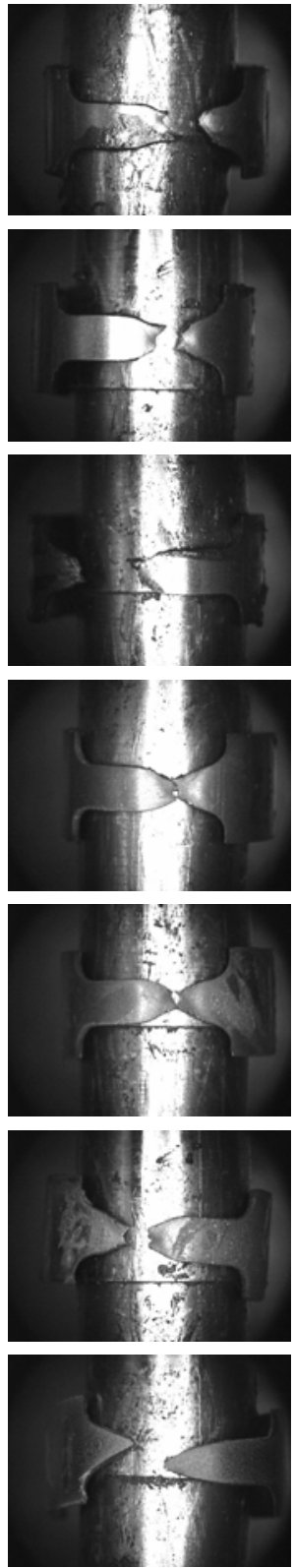

High burn-up cladding

R.T.

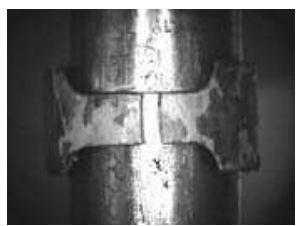

$135^{\circ} \mathrm{C}$

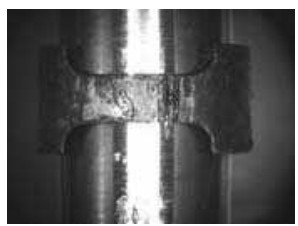

$200^{\circ} \mathrm{C}$

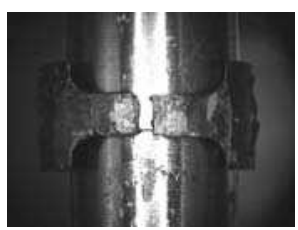

$300^{\circ} \mathrm{C}$

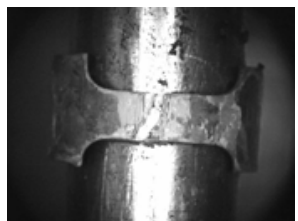

$350^{\circ} \mathrm{C}$

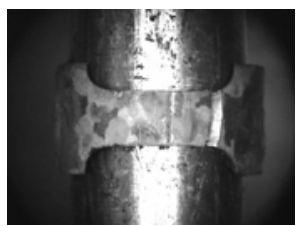

$400^{\circ} \mathrm{C}$

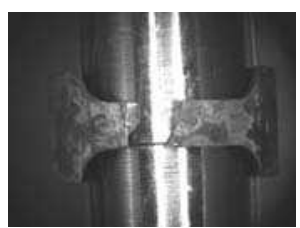

$600^{\circ} \mathrm{C}$

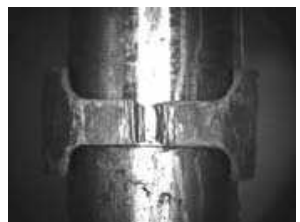

Fig. 8. Stereoscope photograph of the specimens after the ring tensile test 
In conclusion, the fracture type of non-irradiated Zircaloy-4 cladding depends on the temperature, and the behavior is governed by a ductile fracture with a necking. On the contrary, the fracture patterns of the high burn-up Zircaloy-4 cladding showed completely different fracture patterns from the non-irradiated Zircaloy-4 cladding. The fracture type was observed to be vertical in the tensile direction without a necking at all of the test temperatures, which is convincing evidence of the brittle fracture behavior of high burn-up fuel cladding regardless of temperature.

This means that even at a high temperature, $600^{\circ} \mathrm{C}$ or $800^{\circ} \mathrm{C}$, the fracture pattern showed a brittle fracture behavior. Accordingly, it was found that the high burn-up Zircaloy-4 cladding becomes very brittle even at the high temperatures achievable during a designbasis accident (Daum et al., 2002).

\subsection{Evaluation of mechanical properties by high-speed burst test}

Fig. 9 shows the time-pressure profile of the as-received Zircaloy-4 cladding under the rapid pressurization test. In the $350^{\circ} \mathrm{C}$ test, the pressure increased prior to the test which is due to a thermal expansion of the hydraulic oil. It showed that the pressurization rate (slope at the initial part of the time-pressure curve) in this study was $5.4 \mathrm{GPa} / \mathrm{s}$ at room temperature and $3.1 \mathrm{GPa} / \mathrm{s}$ at $350^{\circ} \mathrm{C}$, where the pressurization rate at room temperature is 24,000 times higher than the conventional burst test. As the pressurization changes, the material properties also change. Ultimate hoop stress (UHS) at room temperature and $350 \circ \mathrm{C}$ in this study were, respectively 1,067 and $620 \mathrm{MPa}$, which are increased by 24.3 and $16.8 \%$ when compared to the conventional burst test. In the figure, theoretical burst behavior can be expected when the line was drawn from the elastic region and extended to the baseline, namely the $0 \mathrm{MPa}$ line. When we measure the interval between the intersection point and the point at a failure, the actual duration time of the fuel cladding during a rapid pressurization can be obtained. Duration time of the Zircaloy-4 cladding was $37.8 \mathrm{~ms}$ at room temperature and $32.5 \mathrm{~ms}$ at $350{ }^{\circ} \mathrm{C}$, which closely simulates the power pulse of an actual RIA situation which is known as around 30-40 ms (MacDonald et al., 1970).

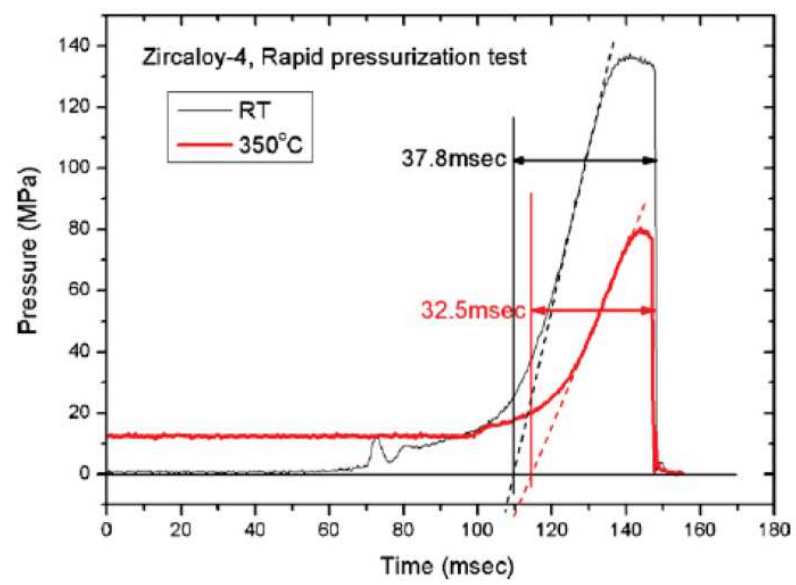

Fig. 9. Rapid burst properties of Zircaloy-4 cladding with the test temperature 
Merging all burst tests into a single graph, the change in the material property as UHS with the pressurization is shown in Fig. 10. In the figure, there exists a linear relationship between the UHS and the pressurization rate. The slope between the UHS and pressurization rate was 0.03701 at room temperature and 0.02124 at $350{ }^{\circ} \mathrm{C}$. From the result, a higher pressurization rate induces a higher strain rate that results in an increase of the UHS. Since the evaluation of the actual strain rate under biaxial burst is extremely difficult, it was tried to indirectly evaluate the strain rate of the cladding and compare to the other data (Kim et al., 2006).

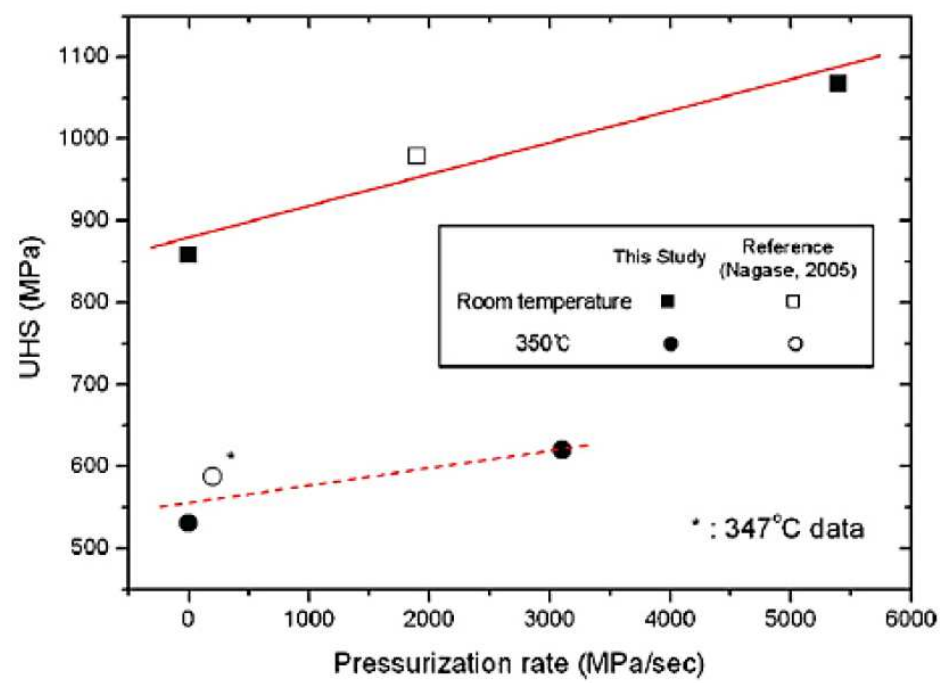

Fig. 10. Changes in the maximum hoop stress of Zircaloy-4 with the pressurization rate and the test temperature.

The result was shown in Fig. 11. As shown in the figure, increase of the maximum stress (both UTS in ring tensile test and UHS in burst test) with the strain rate is clearly shown. Such a strain rate hardening is known as the hindrance of dislocation movement caused by the dislocation multiplication. When an external strain is exerted, dislocations are continuously generated and diffused through the crystal structure to the grain boundary. If the rate of the dislocation generation exceeds the rate of diffusion to the grain boundary, the dislocation density increases to cause an increase in the strength (Adams, 1965). However, it is not clear why the maximum stress as well as the strain rate sensitivity of the burst test is higher than that of the tensile test. Further works related to the strain rate dependency and stress state of the zirconium cladding is needed.

During the waterside corrosion, the generated hydrogen is partly absorbed into the cladding. For hydrogen contents exceeding significantly the solubility limit, hydride precipitation is observed. These precipitated hydrides have a deleterious impact on the fuel cladding ductility (Kim et al., 2006). To investigate the effect of hydrogen, hydrogen was charged into the Zircaloy-4 cladding at a value of 300 and $600 \mathrm{ppm}$ then a rapid pressurization test was carried out. Fig. 12 shows the room temperature rapid 
pressurization profile of the hydrogen-charged Zircaloy-4 cladding. UHS of the 300 ppmcharged specimen did not differ from the as-received condition except that the failure time was more or less shortened. In the case of the $600 \mathrm{ppm}$-charged specimen, it was so brittle that it failed at the elastic region. However, the effect of the hydrogen was soon eliminated when the test temperature was increased. Fig. 13 shows the UHS of the as-received and 600 ppm-charged specimens with the test temperature.

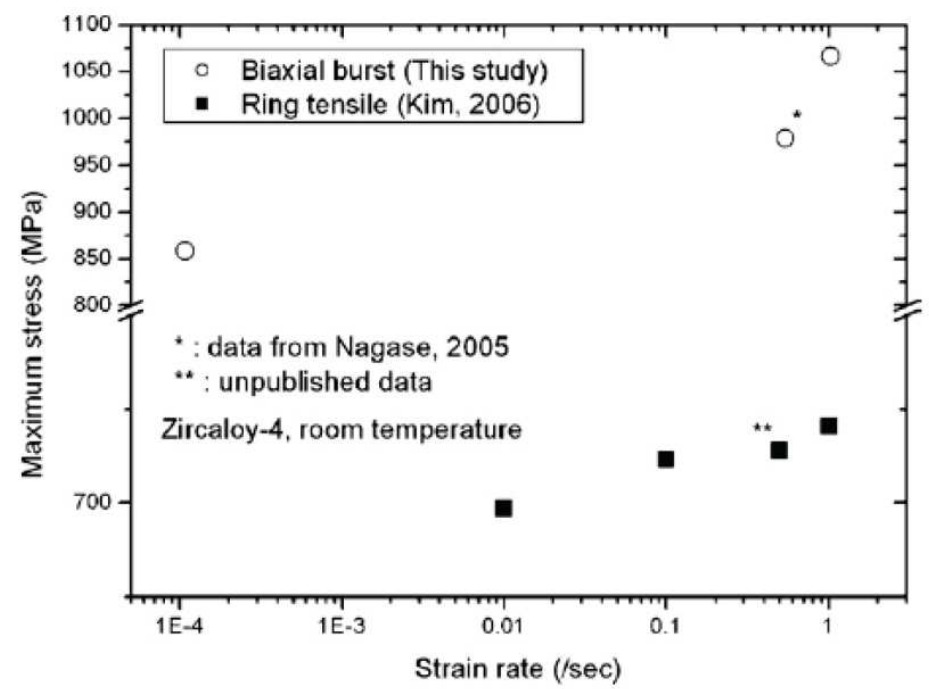

Fig. 11. Changes in the maximum stress of Zircaloy-4 with the strain rate

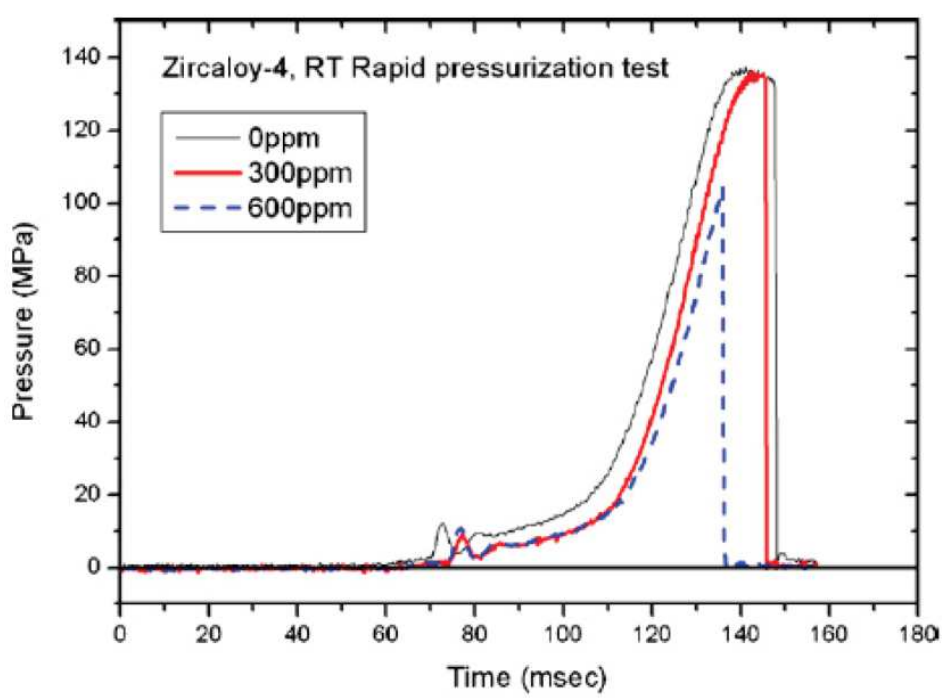

Fig. 12. Rapid pressurization properties of Zircaloy-4 cladding with the hydrogen content 


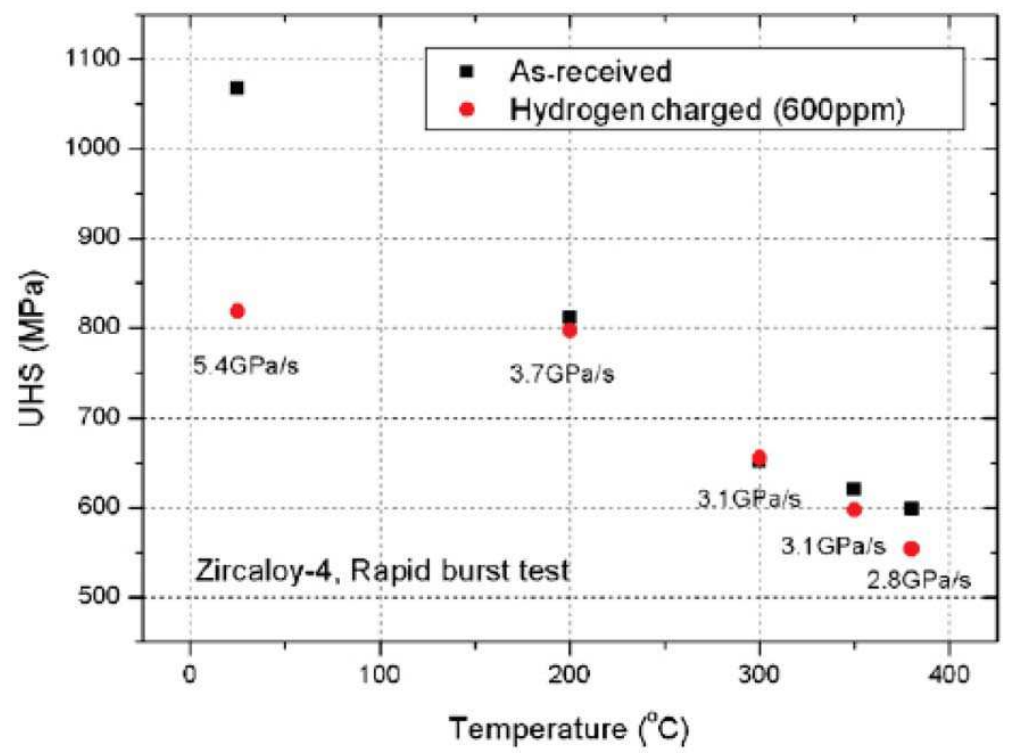

Fig. 13. Maximum hoop stress vs. test temperature

As the test temperature increases, the expansion of the cladding as well as the decrease in the viscosity of the hydraulic oil makes the pressurization rate become lower, which is regarded it as unavoidable. At room temperature, UHS of the as-received condition was $23.2 \%$ larger than that of the 600 ppm-charged specimen. When the temperature increases above $200{ }^{\circ} \mathrm{C}$, their difference cannot be discriminated. At room temperature, the solubility limit of hydrogen is negligible and most of the hydrogen is located in the zirconium hydrides precipitates within the zirconium matrix. These hydrides are responsible for material embrittlement. When it strained at room temperature, separation between the hydride and the metal matrix as well as the failure of a brittle hydride itself will occur to reduce the strength of the zirconium cladding (Kim et al., 2006). When the test temperature increases, the property of the zirconium metal will be changed in that the ductility increases due to an increase in the test temperature. Thus it induces a similar mechanical behavior between the hydrogen-charged cladding and the as-received one. This is also implied from the fracture appearance as shown in the Fig. 14.

In the case of as-received cladding, whatever the testing temperature was, it showed a ductile rupture, creating a circumferentially ballooned state. Crack initiates and propagates along the axial direction above the maximum hoop stress, soon this sharp crack became blunt during a plastic deformation and it ceased to propagate. As-received specimen at $350{ }^{\circ} \mathrm{C}$ showed that the shape of the end part of the ballooned region was dull when compared to the room temperature and $200^{\circ} \mathrm{C}$ condition, which implies that the ductility was increased to suppress the propagation of the axial crack at an elevated temperature. For the 600 ppm-hydrogen-charged cladding pressurized at room temperature, the cladding showed a brittle failure along the axial direction, indicating no plastic deformation. The crack propagates along the axial direction first like the as-received condition, however, this 
sharp crack did not become blunt at the cladding material and it rapidly propagated to induce a catastrophic, brittle failure. A void will nucleate preferentially at an interface between a hydride and a zirconium matrix to develop a crack.

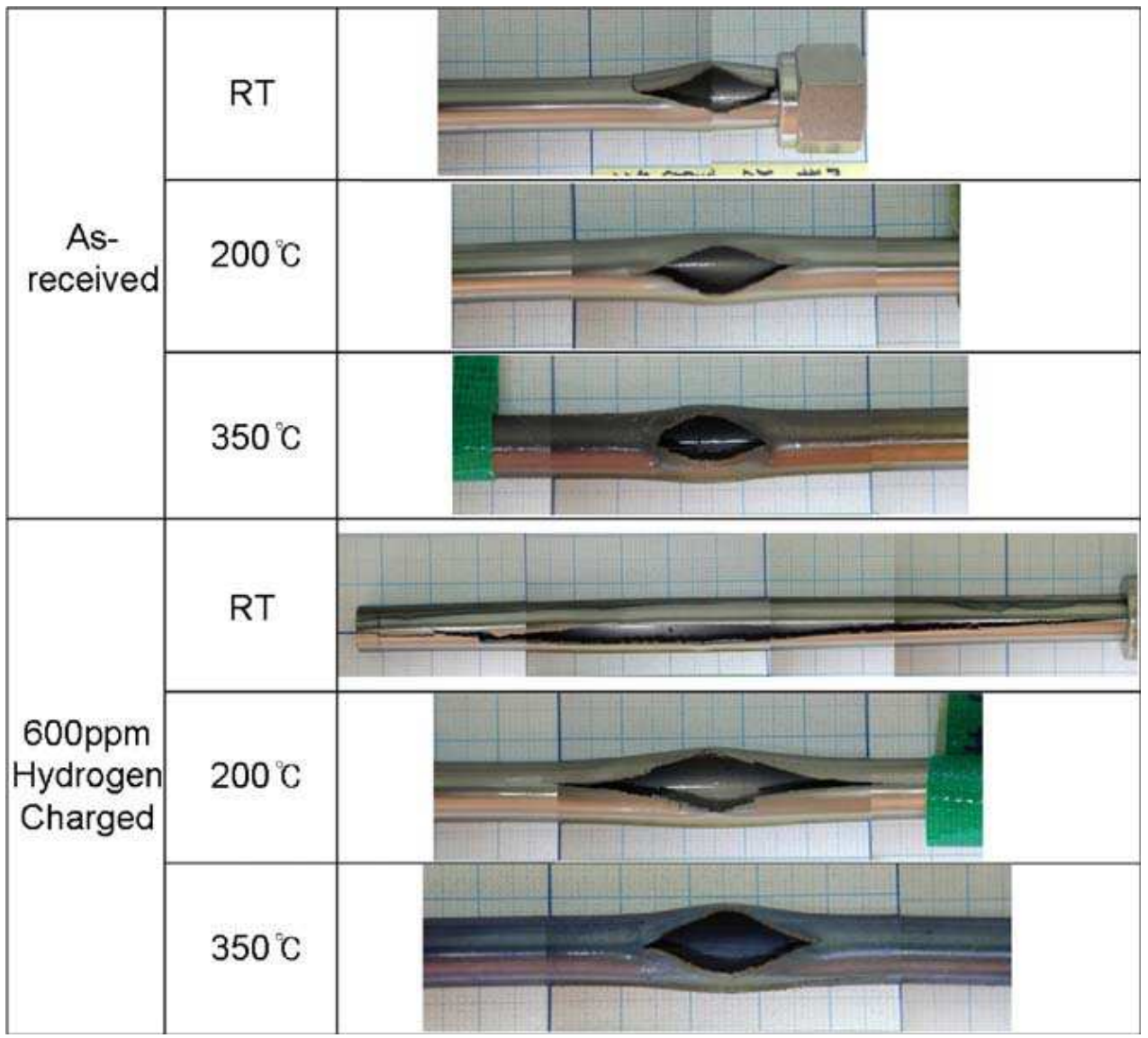

Fig. 14. Fracture appearance of Zircaloy-4 after the high-speed pressurization test

Void will continuously generate ahead of the crack tip when the crack propagates so that it leads to a catastrophic failure along the axial direction. In the case of the hydrogen-charged specimen burst at $200{ }^{\circ} \mathrm{C}$, although the axial cracks developed at the side of the ballooned region, their size was not longer than that at the room temperature. In the case of the hydrogen charged specimen burst at $350^{\circ} \mathrm{C}$, the fracture appearance was no more different than that of the as-received one. In the room temperature, axial split was well developed at the end part cladding which indicates that residual metal is too brittle to suppress the axial crack propagation once the crack initiates at the metal-hydride interface. At the high temperature, such a catastrophic axial crack diminished. This seems that ductility of the metal matrix was so high that it can restrain the crack from propagating, leaving a fracture appearance similar to the as-received one. 


\section{Conclusion}

Main outcomes from CABRI REP-Na program and the current status of CABRI international program (CIP) in water loop test program for investigating fuel and cladding behavior during RIA were presented.

On the basis of the ring tensile tests for the high burn-up Zircalay-4 cladding from Ulchin Unit 2 in Korea and the as-received non-irradiated Zircalay-4 cladding, the following conclusions were drawn. As a result, the mechanical properties are abruptly degraded beyond $600^{\circ} \mathrm{C}$, which corresponds to a design basis accident condition such as a RIA. It was found that the un-irradiated fuel cladding showed ductile fracture behaviors such as $45^{\circ}$ shear type fracture, cup and cone type fracture, cup and cup type fracture and chisel edge type fracture, while the high burn-up Zircalay-4 cladding showed a brittle fracture behavior even at the high temperatures (e.g. over $600^{\circ} \mathrm{C}$ ) which are achievable during a RIA.

Rapid pressurization test was also carried out to evaluate the mechanical behavior of a cladding under a fast strain rate as well as a biaxial stress state to simulate an out-of-pile RIA behavior. The resuts shows that maximum hoop stress, pressurized at a rate of 5.4 $\mathrm{GPa} / \mathrm{s}$ at room temperature and $3.1 \mathrm{GPa} / \mathrm{s}$ at $350 \circ \mathrm{C}$, increased by 24.3 and $16.8 \%$ when compared to the conventional burst test results. It was also revealed that failure mode switched from a ductile ballooning to a brittle failure which leads to an axial split of the cladding when the hydrogen was added at a nominal value of $600 \mathrm{ppm}$ when tested at room temperature. As the test temperature increased, its effect was diminished.

\section{Acknowledgment}

This work was financially supported by the Ministry of Education, Science and Technology in Korea.

\section{References}

Adams, K. H. (1965). Dislocation Mobility and Density in Zinc Single Crystals. Ph.D. Thesis. California Institute of Technology

Averty X. et al. (2003). Tensile tests on ring specimens machined in M5 cladding irradiated 6 cycles, IRSN 2003/50

Chung, H. M. \& Kassner, T. F. (1998). Cladding metallurgy and fracture behavior during reactivity-initiated accidents at high burnup. Nuclear Engineering and Design, Vol.186, pp. 411-427

Daum R. S. et al. (2002). On the Embrittlement of Zircaloy-4 Under RIA-Relevant Conditions. Zirconium in the Nuclear Industry : Thirteenth International Symposium, ASTM STP 1423, PA, pp.702-719

Glasstone, S. \& Sesonske, A. (1991). Nuclear Reactor Engineering, 3rd ed., Krieger Publishing Company, Malabar, Florida, USA

Kim, et al. (2006). Effects of oxide and hydrogen on the circumferential mechanical properties of Zircaloy-4 cladding. Nuclear Engineering and Design, Vol.236, pp.18671873 
MacDonald, P. E. et al. (1970). Assessment of light-water-reactor fuel damage during a reactivity-initiated accident. Nuclear Safety, Vol.21, No.5, pp.582-602

Meyer R. O. et al. (1986). A Regulatory Assessment of Test Data for Reactivity Initiated Accidents. Nuclear Safety, Vol.37, No.4, pp.271-288

Schmitz, F. \& Papin, J. (1999). High burnup effects on fuel behavior under accident conditions: the tests CABRI REP Na, Journal of Nuclear Materials, Vol.270, pp. 55-64 


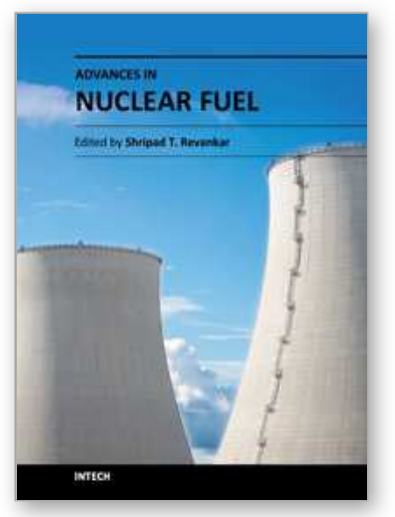

\author{
Advances in Nuclear Fuel \\ Edited by Dr. Shripad T. Revankar
}

ISBN 978-953-51-0042-3

Hard cover, 174 pages

Publisher InTech

Published online 22, February, 2012

Published in print edition February, 2012

Worldwide there are more than 430 nuclear power plants operating and more plants are being constructed or planned for construction. For nuclear power to be sustainable the nuclear fuel must be sustainable and there should be adequate nuclear fuel waste management program. Continuous technological advances will lead towards sustainable nuclear fuel through closed fuel cycles and advance fuel development. This focuses on challenges and issues that need to be addressed for better performance and safety of nuclear fuel in nuclear plants. These focused areas are on development of high conductivity new fuels, radiation induced corrosion, fuel behavior during abnormal events in reactor, and decontamination of radioactive material.

\title{
How to reference
}

In order to correctly reference this scholarly work, feel free to copy and paste the following:

Sun-Ki Kim (2012). Behaviors of Nuclear Fuel Cladding During RIA, Advances in Nuclear Fuel, Dr. Shripad T. Revankar (Ed.), ISBN: 978-953-51-0042-3, InTech, Available from:

http://www.intechopen.com/books/advances-in-nuclear-fuel/behaviors-of-nuclear-fuel-cladding-during-ria

\section{INTECH}

open science | open minds

\section{InTech Europe}

University Campus STeP Ri

Slavka Krautzeka 83/A

51000 Rijeka, Croatia

Phone: +385 (51) 770447

Fax: +385 (51) 686166

www.intechopen.com

\section{InTech China}

Unit 405, Office Block, Hotel Equatorial Shanghai

No.65, Yan An Road (West), Shanghai, 200040, China

中国上海市延安西路65号上海国际贵都大饭店办公楼 405 单元

Phone: +86-21-62489820

Fax: +86-21-62489821 
(C) 2012 The Author(s). Licensee IntechOpen. This is an open access article distributed under the terms of the Creative Commons Attribution 3.0 License, which permits unrestricted use, distribution, and reproduction in any medium, provided the original work is properly cited. 